\title{
PERAN MASYARAKAT DALAM PEMBERANTASAN KORUPSI DI DESA SIDOMULYO
}

\author{
NELVITIA PURBA,SH.M.Hum, Ph. D ${ }^{1)}$, HARDI MULYONO,SE, M AP. ${ }^{2)}$ \\ UNIVERSITAS MUSLIM NUSANTARA \\ AL WASHLIYAH ${ }^{1,2)}$
}

\begin{abstract}
ABSTRAK
Meningkatnya kasus korupsi disebabkan oleh beberapa hal, diantaranya rendahnya moralitas, tidak memiliki budaya malu, tidak taat pada hukum, tidak amanah, tidak jujur, dan lain sebagainya. Oleh karena itu diperlukan adanya langkah-langkah positif diantaranya adalah penyadaran dan pembinaan moralitas bangsa, sehingga penyelenggaraan Negara dapat berjalan dengan baik, yakni bersih dari tindakan Korupsi, Kolusi, dan Nepotisme (KKN). Tindak Pidana Korupsi (TIPIKOR) adalah perbuatan yang menyelewengkan atau menyalahgunakan uang Negara untuk kepentingan pribadi atau orang lain. Memberantas korupsi bukanlah perkara yang mudah. Diperlukan upaya sungguh-sungguh dan didukung oleh semua pihak untuk memberantasnya. Korupsi yang sudah merajalela sangat sulit untuk diberantas.Tidak hanya KPK sebagai lembaga yang secara khusus menangani korupsi, tetapi juga andil masyarakat sangat diperlukan. Metode yang digunakan dalam kegiatan ini adalah ceramah,diskusi,dan tanya jawab tentang permasalahanyang berkaitandenganPeran Dari masyarakat untuk memberantas korupsi. Kesemua metode tersebut diterapkan bersama-sama dalam acara penyuluhan di tempat yang ditentukan. Dari hasil Pengabdian dapat dikemukakan bahwa Peran serta masyarakat dalam memberantas korupsi adalah sebagai informan atau penyuplai informasi. Dalam hal ini masyarakat berperan mengambil inisiatif untuk melaporkan, membeberkan dan memberikan informasi kepada aparat penegak hukum terhadap kemungkinan terjadinya praktek korupsi.
\end{abstract}

Kata Kunci : Masyarakat, penyuluhan hukum.Pemberantasan Korupsi.

\begin{abstract}
Increasing corruption cases caused by several things, including the lack of morality, does not have a culture of shame, do not obey the law, not the mandate, dishonest, etc. It is therefore necessary the existence of positive measures such as awareness and the construction of morality of the nation, so that the conduct of the State can run well, i.e. clean from corruption, collusion, and Nepotism (KKN). Criminal acts of corruption (TIPIKOR) is the Act of distorting or misusing state money for personal gain or other people. Anti-corruption is not an easy matter. Painstaking efforts are needed and supported by all parties for memberantasnya. Rampant corruption is already very difficult to enforce. Not only the KPK as institutions that specifically deal with corruption, but also the participation of the community is indispensable. The methods used in this activity is a lecture, discussion, and q \&amp; a about the permasalahanyang berkaitandenganPeran of the society to eradicate corruption. All of these methods are applied together in the event of extension in the specified place. From the results of Devotion can be expressed that the role of the community in eradicating corruption is as informants or information suppliers. In this case the community takes the initiative to report the acts, expose and provide information to law enforcement agencies to the possibility of the occurrence of corruption practices.
\end{abstract}

Key words: community, the extension of the law. The Eradication Of Corruption.

\section{PENDAHULUAN}

Sumatera Utara saat ini sebagai daerah yang paling tinggi angka terjadinya kasus korupsi dan berdasarkan data yang dihimpun oleh Lembaga bantuan Hukum (LBH) Medan, tercatat kasus korupsi meningkat 100 persen sepanjang tahun
2012 jumlah kasus korupsi pada tahun 2011 sebanyak 13 kasus, sementara pada tahun 2012 meningkat menjadi 26 kasus.

Berdasarkan data yang dilansir oleh Forum Transparansi Indonesia untuk anggaran (Fitra) wilayah Sumatera Utara dari hasil audit Badan 
Pemeriksa Keuangan (BPK) pada ikhtisar hasil pemeriksaan (IHP) Semester II tahun 2012 .Menempatkan Sumatera Utara sebagai propinsi terkorup di Indonesia.Propinsi Sumatera Utara menduduki peringkat pertama disusul oleh Propinsi Aceh, Papua Barat, DKI Jakarta peringkat keempat. Pematang Siantar menurut Forum Indonesia Untuk Transparansi Anggaran (Fitra) meraih peringkat keempat setelah Kabupaten Langkat, Medan Dan Kabupaten Batubara dari 10 Kabupaten yang di Sumatera Utara terkorup di Sumatera Utara. Hal ini berdasarkan hasil iktisar audit Badan Pemeriksaan Keuangan (BPK).

Meskipun data kuantitatif di atas menunjukkan ada trend peningkatan kasus korupsi di Indonesia, karena kepolisian, kejaksaan dan KPK telah semakin gencar menyeret pelaku korupsi ke pengadilan, tetapi dari data kuantitatif tersebut menujukkan bahwa semakin gencar penanggulangan korupsi menggunakan instrument pidana (tindakan represif), sebaliknya menunjukkan bahwa korupsi makin marak, bahkan bagaikan virus yang menyebar keseluruh lini kehidupan.

Berpijak kepada kondisi objektif penanggulangan korupsi di Indonesia dan permasalahan tersebut perlu kiranya diketahui terlebih dahulu apa yang dimaksud dengan pengertian tentang integral dan pengertian sistemik. Oleh karena itu dalam rangka agar penanggulangan korupsi tersebut dapat lebih optimal, maka harus diintegrasikan dengan strategi nasional yaitu pemberantasan korupsi melalui kebijakan pencegahan (tindakan preventif)terhadap kondisi yang dapat menstimulus terjadinya korupsi, atau dengan kata lain akar masalah yang memicu seseorang untuk melakukan perbuatan korupsi. \begin{tabular}{lll}
\multicolumn{2}{c}{ Penanggulangan } & korupsi \\
dengan mengsinergikan & strategi \\
penindakan dan pencegahan & sejalan
\end{tabular} dengan hasil Kongress PBB mengenai Pencegahan (preventif), sejak kongres ke-5 Tahun 1975 di Jenewa sampai dengan Kongres ke 11 di Bangkok 1825 April 2005, merekomendasikan bahwa penanggulangan korupsi harus di tempuh dengan pendekatan secara integral (komprehensif), baik preventif, refresif, dan edukatif.

Hal ini dikuatkan berdasarkan dari rekomendasi 5th Annual Comference And General Meeting International Association Of AntiCorruption Authorities (IAACA) pada tanggal 22-23 Oktober 2011 di Marrakech Morocco, bahwa penanggulangan korupsi ke depan seyogyanya melalui pendekatan 4 pilar yaitu : prevention, education, repression, dan cooperation.

Suatu negara terdiri dari tiga komponen utama yaitu pemerintah, masyarakat,dan swasta. Keberhasilan suatu negara sangat tergantung pada kinerja dan kerja samaketiganya. Jika kerjasama yang dilakukan baik maka akan menjadi bagus negara itu,sebaliknya jika buruk maka cepat atau lambat bangsa itu akan hancur. Oleh karenaitu, masyarakat harus aktif ikut dalam upaya perbaikan bangsa ini.

KPK bukan dewa, sebagai satu-satunya lembaga yang masih dipercaya menangani masalahkorupsi, mempunyai keterbatasan.Meski dimungkinkan membuat perwakilan didaerah, sampai saat ini KPK hanya ada di Jakarta sedangkan korupsi terjadi di mana-mana.KPK mempunyai jumlah personil yang tidak seberapa jika dibandingkandengan seluruh kasus korupsi yang terjadi.Di sinilah dibutuhkan bantuan masyarakatuntuk 
mengawasi, memberikan aduan, dan pembinaan agar mengurangi beban KPK.

Sudah menjadi pengetahuan umum bahwa aktor utama korupsi adalah pemerintah dan pengusaha, Sementara masyarakat adalah korbannya. Kolaborasiantara pemerintah dengan pengusaha menimbulkan kesengsaraan bagi masyarakat pada umumnya. Hampir sebagian besar kasus korupsi yang terungkap selalu menempatkan dua aktor itu sebagai biang keladi yang saling berkaitan. Entah relasinya berwujud simbiosis mutualisme ataupun parasitmutualisme yaitu korupsi yang dimensinya adalah pemerasan.

Jikapun masyarakat kemudian terseret dalam arus kehidupan koruptif, hal itusemata-mata karena upaya terpaksa yang dilakukan untuk bisa memperoleh hakhaknya.Kebiasan untuk membayar lebih dari harga yang ditetapkan peraturan kepada petugas dalam pengurusan ijin seperti SIM, KTP, STNK dan lain sebagainya, merupakan wujud dari ketidakberdayaan masyarakat untuk melawan sistem para koruptor.

Peran Aktif Masyarakat Dalam Melawan Korupsi - Peran aktif kita sangat diharapkan dalam pemberantasan korupsi di negara ini, demi mewujudkan Indonesia yang bebas dari korupsi. Jika kita mengetahui adanya dugaan tindak pidana korupsi, segera laporkan kepada KPK. Kita juga perlu memberikan apresiasi terhadap instansi pemerintah dan pegawainya yang telah melakukan pelayanan publik dengan baik.

Bentuk-bentuk peran serta masyarakat dalam memberantas korupsi, antara lain:
Pertama, peran sebagai informan atau penyuplai informasi. Dalam hal ini masyarakat berperan mengambil inisiatif untuk melaporkan, membeberkan dan memberikan informasi kepada aparat penegak hukum terhadap kemungkinan terjadinya praktek korupsi. Untuk mewujudkan peran ini, maka yang harus dimiliki oleh masyarakat adalah rasa peka dan kewaspadaan yang tinggi terhadap proses penyelenggaraan pemerintah daerah dan pembangunan. Adanya sikap semacam ini akan memicu keingintahuan masyarakat (secara dalam dan luas) pada hal-hal yang berlaku di sekitarnya. Dengan demikian jawaban atas keingintahuan masyarakat tersebut sangat potensial menjadi data dan informasi sebagai salah satu sumber data yang berguna untuk disampaikan kepada penegak hukum atas adanya indikasi praktek korupsi. Hal yang sangat membantu akhir-akhir ini adalah kebebasan memperoleh informasi telah menjadi produk kebijakan yang memaksa semua pejabat publik untuk membuka akses informasinya kepada masyarakat. Dalam kondisi ini, sangat memungkinkan laporan-laporan terjadinya kasus korupsi dapat terus mengalir, sehingga praktek korupsi akan dapat diminimalisir.

\section{METODE PELAKSANAAN}

Metode yang digunakan dalam kegiatan ini adalah ceramah, diskusi, dan tanya jawab tentang permasalahan yang berkaitan dengan Peran Dari masyarakat untuk memberantas korupsi. Kesemua metode tersebut diterapkan bersamasama dalam acara penyuluhan selama 1 hari di tempat yang ditentukan.

Pada hari yang telah 
Masyarakat dari LP2M UMN AW Medan mendatangi tempat kegiatan yaitu Di Desa Sidomulyo Kecamatan Sibiru-Biru untuk memberikan pembekalan dalam bentuk Penyuluhan Hukum yang bertema "Peran Masyarakat Untuk pembudayaan Anti Korupsi “

Pembekalan dilakukan dengan metode ceramah yang kemudian diikuti dengan kegiatan tanya jawab dengan masyarakat dan tim dari Penyuluhan Hukum dari Fakultas Hukum UMN AW Medan.

Pada saat metode ceramah yang digunakan dalam Penyuluhan Hukum ini Tim dari Fakultas Hukum UMN AW juga langsung menggunakan metode tanya jawab kepada Masyarakat.

Pertanyaaan yang diajukan kepada para peserta penyuluhan hukum menunjukkan bahwa masih belum pahamnya mereka tentang apa yang dikatakan "Korupsi" dan cara berperan serta untuk ikut menanggulanginya. Namun mereka mengerti bahwa upaya pemberantasan dari korupsi tersebut membutuhkan kerjasama dari semua lapisan / semua pihak.yang bukan hanya pemerintah yaitu aparat penegak hukum tetapi juga masyarakat dan keluargakeluarga inti.

Dari Pertanyaan-pertanyaan yang diajukan oleh masyarakat tersebut tidak hanya berkaitan dengan topik kegiatan namun lekat dengan kehidupan mereka sehari-hari yang berkaitan dengan hukum, mengingat Kecamatan Medan Sunggal perlunya diberinya pemahaman tentang Peran Dari Masyarakat.

Karena ketidakpahaman dari Peserta yaitu Masyarakat menunjukkan bahwa upaya pemberantasan korupsi tersebut menghadapi jalan yang sangat
panjang.Adalah tidak mungkin mengharapkan mereka untuk ikut serta dalam usaha untuk pemberantasan korupsi jika pemahaman tentang korupsi tersebut masih minim.

\section{HASIL DAN PEMBAHASAN}

Peran Aktif Masyarakat Dalam Melawan Korupsi - Peran aktif kita sangat diharapkan dalam pemberantasan korupsi untuk mewujudkan negara Indonesia yang bebas dari korupsi. Jika kita mengetahui adanya dugaan tindak pidana korupsi, segera laporkan kepada KPK. Kita juga perlu memberikan apresiasi terhadap instansi pemerintah dan pegawainya yang telah melakukan pelayanan publik dengan baik.

Tidak perlu khawatir dan ragu. Undang-undang telah memberikan hak dan melindungi kita untuk melakukan pelaporan ini. KPK menjamin kerahasiaan identitas, selama pelapor tidak mengungkapkannya. Anda dapat memantau perkembangan laporan anda dengan membuka kotak komunikasi rahasia tanpa khawatir identitas Anda akan diketahui oleh siapapun. Karena itu, tunggu apalagi. Sekaranglah saat yang tepat untuk ambil bagian dalam menyelamatkan bangsa ini dari kehancuran akibat korupsi.

\section{Mengapa Kita harus melaporkan dugaan korupsi?}

Korupsi telah menyebabkan kerugian luar biasa bagi bangsa ini. Jika kondisi ini dibiarkan, maka citacita luhur bangsa untuk mensejahterakan rakyat Indonesia akan sangat sulit untuk dicapai. Yakinlah, bahwa tanpa korupsi, 
negara ini akan jauh lebih baik. Karena itu, korupsi harus dilawan bersama-sama.

Peran serta masyarakat merupakan elemen terpenting dalam pemberantasan korupsi. Tanpa dukungan Anda dan segenap masyarakat Indonesia lainnya, segala upaya pemberantasan korupsi tidak akan berjalan secara efektif. Karena itulah, Undang-undang memberikan hak dan perlindungan kepada masyarakat untuk berpartisipasi dalam pemberantasan korupsi.

Salah satu bentuk dukungan itu adalah dengan melaporkan dugaan tindak pidana korupsi dan juga tindakan anti-korupsi yang terjadi di sekeliling Anda kepada kami. Dengan melakukan hal tersebut, maka Anda telah mengambil bagian penting dalam upaya perjuangan bangsa ini melawan korupsi.

\section{Penggalangan Masyarakat \\ Keikutsertaan}

Dibutuhkan peran strategis masyarakat untuk mencegah, mendeteksi serta memberantas korupsi. Hanya masih disayangkan berbagai kebijakan Pemerintah yang berkaitan dengan strategi pemberantasan korupsi belum mendukung adanya peran serta masyarakat yang lebih strategis. Sebab tanpa didukung dengan kebijakan pemerintah yang menguntungkan, masyarakat telah memainkan perannya dalam pemberantasan korupsi di berbagai aras.

\begin{tabular}{lcr}
\multicolumn{2}{c}{ Bentuk-bentuk } & peran serta \\
masyarakat dalam & memberantas \\
korupsi, & antara & lain:
\end{tabular}

Pertama, peran sebagai informan atau penyuplai informasi. Dalam hal ini masyarakat berperan mengambil inisiatif untuk melaporkan, membeberkan dan memberikan informasi kepada aparat penegak hukum terhadap kemungkinan terjadinya praktek korupsi. Untuk mewujudkan peran ini, maka yang harus dimiliki oleh masyarakat adalah rasa peka dan kewaspadaan yang tinggi terhadap proses penyelenggaraan pemerintah daerah dan pembangunan. Adanya sikap semacam ini akan memicu keingintahuan masyarakat (secara dalam dan luas) pada hal-hal yang berlaku di sekitarnya. Dengan demikian jawaban atas keingintahuan masyarakat tersebut sangat potensial menjadi data dan informasi sebagai salah satu sumber data yang berguna untuk disampaikan kepada penegak hukum atas adanya indikasi praktek korupsi. Hal yang sangat membantu akhir-akhir ini adalah kebebasan memperoleh informasi telah menjadi produk kebijakan yang memaksa semua pejabat publik untuk membuka akses informasinya kepada masyarakat. Dalam kondisi ini, sangat memungkinkan laporan-laporan terjadinya kasus korupsi dapat terus mengalir, sehingga praktek korupsi akan dapat diminimalisir.

Kedua, peran sebagai penyebar isu. Sudah bukan rahasia umum lagi kalau priorotas penanganan kasus-kasus pelanggaran hukum yang ada kaitannya dengan korupsi di negara ini tergantung pada seberapa luas isu dugaan korupsi itu menyebar dan sejauhmana media memberitakannya. Dalam kaitan inilah masyarakat berperan sebagai pemicu atau penyebar isu. Strategi ini menjadi sangat penting untuk membentuk opini atau persepsi masyarakat bahwa di satu tempat diduga kuat terjadi praktek korupsi, sekaligus sebagai respon atas rendahnya inisiatif aparat penegak 
hukum dalam membongkar kasuskasus korupsi. Kebekuan ini perlu diterobos dengan memberikan informasi adanya dugaan korupsi kepada media massa supaya diketahui masyarakat luas. Situasi ini diharapkan akan dapat memaksa aparat penegak hukum untuk melakukan tindakan-tindakan yang konkrit. Strategi ini memang berisiko, misalnya dituntut dengan pencemaran nama baik, namun upaya itu tetap tidak bisa ditinggalkan.

Ketiga, peran sebagai pengawas. Tidak jarang bila laporan masyarakat tentang terjadinya kasus korupsi sering tidak ditanggapi dengan baik oleh aparat penegak hukum. Penegak hukum seringkali beranggapan bahwa Informasi atau data yang disampaikan oleh masyarakat semata-mata sebagai alat untuk memeras. Dalam kaitan inilah masyarakat tampil sebagai pengawas dan berperan untuk mengawal proses pengusutan kasus korupsi yang sedang dilakukan oleh aparat. Kegiatan unjuk rasa, dengar pendapat, diskusi publik, audiensi dan lain sebagainya merupakan sarana yang kerap digunakan kelompok masyarakat untuk mendorong percepatan penanganan korupsi. Memastikan bahwa pemberantasan korupsi berjalan sesuai dengan harapan merupakan langkah yang tidak mungkin diabaikan ditengahtengah situasi aparat penegak hukum yang lamban dan setengah hati mengusut laporan.

Keempat, pesan moral melalui pendidikan. Satu hal yang tidak boleh terabaikan adalah proses pendidikan bagi anak-anak dalam keluarga. Perilaku korupsi pada prinsipnya tidak dapat dipisahkan dengan kualitas moral para pejabat publik pelaku korupsi. Disinilah masyarakat memiliki peran strategis untuk membekali anak-anak dalam keluarga melalui pendidikan nilai yang diwariskan kepada anak-anak secara turun-temurun. Melalui pendidikan karakter yang baik sejak usia dini terutama dalam keluarga, dapat diharapkan kelak anak-anak menjadi orang dewasa yang tidak mudah tergoda dengan sikap dan perilaku korupsi.

Untuk mewujudkan hal itu, diperlukan penggalangan masyarakat. Tujuan yang ingin dicapai oleh strategi penggalangan keikutsertaan masyarakat ini adalah terbentuknya suatu keikutsertaan dan partisipasi aktif dari segenap komponen bangsa dalam memberantas korupsi.

\section{Contoh Peran Serta Masyarakat Dalam Pemberantasan Korupsi \\ Peran serta masyarakat} tersebut meliputi tentang hak dan tanggung jawab masyarakat. Beberapa hak masyarakat ialah :

a. Berhak mencari, memperoleh, dan memberikan informasi adanya dugaan telah terjadi tindak pidana korupsi, serta menyampaikan saran dan pendapat kepada penegak hukum dan atau Komisi mengenai perkara tindak pidana korupsi;

b. Penyampaian informasi, saran dan pendapat, atau permintaan informasi harus dilakukan secara bertanggungjawab sesuai ketentuan peraturan perundangundangan yang berlaku, norma agama, kesusilaan, dan kesopanan.

c. Setiap orang, organisasi masyarakat, atau lembaga swadaya masyarakat berhak atas perlindungan hukum baik mengenai status hukum maupun rasa aman. 


\section{KESIMPULAN}

Peran serta masyarakat dalam memberantas korupsi adalah sebagai informan atau penyuplai informasi. Dalam hal ini masyarakat berperan mengambil inisiatif untuk melaporkan, membeberkan dan memberikan informasi kepada aparat penegak hukum terhadap kemungkinan terjadinya praktek korupsi. Untuk mewujudkan peran ini, maka yang harus dimiliki oleh masyarakat adalah rasa peka dan kewaspadaan yang tinggi terhadap proses penyelenggaraan pemerintah daerah dan pembangunan.

\section{REFERENSI}

Aziz Syamsuddin,2011,Tindak Pidana Khusus,Sinar Grafika Jakarta.

Bibit Samad Rianto,2009,UndangUndang Pengadilan Tipikor Dan Eksistensi Komisi Pemberantasan Korupsi, dalam Amir Syarifudin, dkk (penyunting) Bunga Rampai Potret Penegakan Hukum di Indonesia,Jakarta : Komisi Yudisial Republik Indonesia.

Ermanjah Djaja,2010,Meredesain Pengadilan Tindak Pidana Korupsi (Implikasi Putusan Mahkamah Konstitusi Nomor 012-016-019/PPU-

IV/2006,Sinar Grafika Jakarta.

Hamzah Andi, 1991, Korupsi di Indonesia Masalah Dan Pemecahannya Jakarta: PT Gramedia.

Handoyo Eko, 2009, Pendidikan Anti Korupsi,Semarang Widyakarya Press.
ICW,2000,Peran Parlemen Dalam Membasmi Korupsi Jakarta ; ICW.

Juniver Girsang,2012,Abuse Power (Penyalahgunaan Kekuasaan Aparat Penegak Hukum Dalam Penanganan Tindak Pidana Korupsi,JG Publishing.

Marwan Effendy,2011,Kapita Selecta Hukum Pidana (Perkembangan Dan Isu-Isu Aktual Dalam Kejahatan Finansial Dan Korupsi),Referensi Jakarta.

Martiman

Prodjohamidjojo,2001,Penerapa

n Pembuktian Terbalik Di

Dalam Delik Korupsi,Mandar Maju Bandung

Peter

Marzuki,2011,Penelitian

Hukum,Kencana Prenada

Media Group Jakarta.

Satjipto Rahardjo,1983,Hukum Dan Perubahan Sosial Suatu Tinjauan Teoritis Serta Pengalaman-Pengalaman Di Indonesia,Alumni Bandung.

Sulistyantoro,HT,2004,Etika Kristen Dalam Menyikapi Korupsi, Kompas,Senin , 2 Agustus 2004.

Syaiful Bakhri,2009,Pidana Denda Dan Korupsi,Total Media Jakarta.

Sudarsono,2007,Kamus

Hukum,Rineka Cipta Jakarta.

Syahrial,Aliaras Wahid, H.A Djasli,Sugeng

Wibowo,2006,Membangun 
Karakter Dan Kepribadian

Melalui Pendidikan

Kewarganegaraan,University

Press jakarta.

Peraturan Perundang-undangan :

Undang-Undang Dasar Tahun 1945 Hasil Amandemen.

Undang-undang Republik Indonesia Tentang Tindak Pidana Korupsi Nomor 31 Tahun 1999 Jo Undang-Undang Republik Indonesia Nomor 20 Tahun 2001.

Undang-Undang Republik Indonesia Nomor 30 Tahun 2002 Tentang Komisi Pemberantasan Tindak Pidana Korupsi. 